\title{
The Good Community: Practical Wisdom, Organizational Purpose, and the Rule of St. Benedict
}

\author{
Giorgio Mion* \\ Riccardo Tessari \\ University of Verona \\ Department of Business Administration \\ ViaCantarane, 24, 37129 Verona, Italy
}

\begin{abstract}
In some managerial approaches there is the hidden risk of reducing people to their rational capabilities applied to decision-making; on the contrary, people cannot suppress their deep nature, which involves emotions and spirituality in all their actions. This paper starts from this point of view and explores the importance of practical wisdom to build institutions that work toward the common good. The paper explores the Rule of St. Benedict (RSB) as a crucial source of spiritual capital that can help the development of practical wisdom for management. The research highlights three strongly related characteristics of the RSB: the coenobitical nature of Benedictine communities, the vision of abbots as "prudent managers", and the role of manual labor in monastic daily life. This analysis reveals several managerial implications of the RSB; in particular, with regard to the recognition of the purpose of organizations, which exceeds the narrow limits of individual (profitable) goals.
\end{abstract}

Keywords: Practical Wisdom, Common Good, Organizational Purpose, Rule of St. Benedict, Catholic Social Thought, Ethical Management, Purpose, Virtue Ethics

\section{Introduction}

In line with neoliberistic vision of firm, some approaches to management have been founded as techniques that allow the government of a business as a deterministic system. This vision removes relational and ethical capabilities from managerial skills and denies the human dimension of management (Melé, 2003; Spitzeck, 2011). This situation seems to be the consequence of a reductive vision of both people at work and firms as mere instruments of profit-seeking (Fontrodona \& Sison, 2006). On the contrary, other scholars have identified at the base of a business a community of people (Melé, 2012; Solomon, 1994). The individual goals that motivate people in organizations do not deny an organizational ontology that exceeds those individual goals. Therefore, the common good can define the ontology of organizations (R. G. Kennedy, 2006).

Reintroducing ethical categories into management as practical wisdom and virtues makes it possible to go beyond a disruptive individualistic vision of people that cannot fully activate all human, relational capabilities. In other words, the reductive vision of the firm and its purpose reflects the vision of a person as a "one-dimensional man" (Marcuse, 1964), without an affective and spiritual life that can positively affect their managerial style (Brophy, 2015). Furthermore, if managers are one-dimensional men, all their efforts to maximize individual profits inhibit the common good and, finally, the full achievement of organizational purpose. Nevertheless, this change of paradigm does not affect only individual dimension of management, but concerns also the purpose of firms.

In this paper, we adopt the RSB as a source of practical wisdom that can help managers, entrepreneurs, and workers to recognize the common good as the final purpose of their organizations and to adopt consistent behaviors.

\section{The notion of "practical wisdom" and the common good}

Aristotle presents the notion of phronessis (practical wisdom or prudence) as a dianoetic virtue that allows one to decide well; the "good" decisions taken on the basis of practical wisdom are not always the best ones, but the better ones with respect to what is "right" for the decision-maker (and also for the community and humanity in its entirely). This characteristic of practical wisdom does not deny the existence of a universal right, but it interprets this right in the particular context and at the specific time at which the decision-maker must determine the "good" choice. In Aristotelian thought, practical wisdom requires all other virtues and makes moral action an objective of action itself. 
After having choose the end of the action, practical wisdom operates in choosing instruments useful to reach goals that are decided upstream; so practical wisdom does not determine "why" the individual acts, but "how" they can act to reach their goals. Nevertheless, objectives are not indifferent: a wise person operates well to reach eudaimonia; or happiness, the final objective of human life, according to Aristotle.

Even if it is related to intellect, practical wisdom is not a science, because its object is not independent from the decision itself: practical wisdom can be identified as decisions that become praxis (Puleen \& Kupers, 2013, p. 22 ss). Furthermore, practical wisdom is clearly separate from the other dianoetic virtue (sophia; that is, the capability of knowledge and understanding); while sophía can be developed by studying, phronessis is the fruit of experience and consists of a wise posture facing decision-making (Smith, 2019). In Aristotelian words, practical wisdom-also translated as "prudence"- is the characteristic of a man able "... to deliberate well about what is good and advantageous for himself, not in some one department, for instance what is good for his health or strength, but what is advantageous as a means to the good life in general" (Aristotle \& Rackham, 1982, Chapter VI.5).

There is an essential relationship between practical wisdom and the common good, because the "phronetic" decisionmaking process aims to achieve objectives that cannot be reduced to an individual, fleeting interest, but are connected to the deep sense of human life. It is remarkable that for Aristotle the individual is always social and his or her actions are framed in a community. In Aristotelian thought, ethical action becomes possible thanks to the dianoetic virtue of practical wisdom; in other words, Aristotle connects the objective of human life (the right itself) to the capacity to assume decisions and act on them. The Aristotelian approach to humankind, and overall, modern ethical philosophy, takes into account the relational vocations of all people, who are destined to live in communities where happiness (right) is related to individual happiness (right) (Scheler, 1913; Spaemann, 1989). Consequently, even if Aristotelian writings do not cite the notion of common good as we know it in contemporary ethical debate (Maritain, 1947; Murphy, 2005), it seems clear that we can see practical wisdom as the virtue of making decisions devoted to the common good. When the decision-makers choose the right solution to a problem, they solve the issue with regard to their individual good as well as that of the community in which they participate, because their participation in a community affects their moral character (Koehn, 1995). The category of common good is largely debated and is not univocal, above all because it has been included into different cultural framework like, in particular, Catholic Social Thought (Hittinger, 2008). The notion of common good has been interpreted also with explicit reference to businesses and management (Argandoña, 1998; Melé, 2012; Melé \& Schlag, 2015; Schlag \& Mercado, 2012; Sison \& Fontrodona, 2012, 2013).

Practical wisdom concerns individual decisions, but also affects the social dimensions of the individual; therefore, there is a logical connection between the practical wisdom of the participants in an organization and the institution itself. We cannot reduce practical wisdom to the narrow boundaries of individual behavior, because it is the fruit of good experience, lived in good communities, which aims to attain a good purpose.

Practical wisdom has no elective sphere, but it can be evident and become praxis in all human fields of action. Modern applications of the concept of practical wisdom are inherent to politics, education, and management (Kinsella \& Pitman, 2012; Puleen \& Kupers, 2013; Schwartz, 2011). The first managerial implication of practical wisdom regards business ethics and the two-fold dimension of managerial action: the definition of organizational purpose, and decisions about the best tools to reach organizational objectives. Practical wisdom operates in the decision-maker and becomes applied decisions; so we can see management responsibility as an ethical issue (Fowers, 2003) that depends on managers' virtues (Intezari \& Pauleen, 2014). Practical wisdom is inclusive, operates at the level of organizational actions, and affects them, because managers cultivate their phronessis better if they live a community devoted to good purposes and composed by good human relationships.

\section{Practical wisdom, religious experience, and management}

As a dianoetic virtue distinguished from knowledge, practical wisdom grows by experience and cannot be learned by studying or applying technical skills. Ethical reflection and communitarian life can feed practical wisdom because they allow one to build relationships with other people and to connect the individual dimension of life with the social and spiritual dimensions. If social capital affects practical wisdom and managerial behavior (Burt, 1997, 2000; Coleman, 1990), spiritual experience - as well as philosophical reflection - can generate a "phronetic" approach to decisionmaking (Lenssen, Roosevelt Malloch, Cornuel, \& Kakabadse, 2012).

Spiritual capital is closely related to religious tradition and entails an ethical vision that becomes both religious and social praxis (Baker \& Skinner, 2005, p. 4). Scholars have recognized that spiritual capital is difficult to define and, overall, to measure (Iannaccone \& Klick, 2003; Keller \& Helfenbein, 2008), because it does not concern intellectual capabilities or "mere" knowledge accumulated by studying. 
Individual and communitarian religious experience feeds spiritual capital that can be embodied in oral and written traditions, liturgical practices, rules of life, etc. In other words, if we can recognize social capital only in reference to mutual relations between people in a specific context and at a particular historical moment (Putnam, 2000, pp. 18-19), spiritual capital is a manifestation of social capital that grows and spreads by means of memory and custom (Roosevelt Malloch, 2010), in connection with heartfelt human needs.

If social or spiritual capital nourishes practical wisdom by accumulating life experiences and cultural traditions, this dianoetic virtue produces good practices; spiritual capital accumulation is positively correlated with the common good (Koenig \& Lewis, 2000; Wortham \& Wortham, 2007) in the different aspects that this notion assumes for human life, as well as in the professional and business spheres. Spiritual experience does not end in religious practice - even if it is strictly connected to religion - but enters social, political, and economic relations, because a spiritual approach to life guides individual thought and action. There is a two-fold dimension to spiritual capital: on one hand, it is a common asset fed by widespread tradition; on the other hand, there is the individual dimension of religious experience that allows a personal accumulation of spiritual capital.

Some scholars affirm that spiritual capital is related to specific religious experience (Berger \& Hefner, 2003), while others assert that there is a wider relationship between spiritual capital and religious experience itself (Gràcia, 2012). Even if personal religious practice has a clear effect on spiritual capital accumulation, there are some deposits fully accessible to all people, because they are the fruit of the millennia of experience of all humanity-or specific communities - and an important aspect of cultural and social heritage. Their crystallization in literary texts allows a general access to spiritual capital, available also to people that do not adhere to a religious community; but as part of humankind, have universal spiritual instances (Zohar \& Marshall, 2004, p. 29). Therefore, the access to spiritual capital becomes freer and simpler via the medium of millenarian religious tradition embodied in literary texts.

Scholars have explored the relationship between practical wisdom, religious, and philosophical tradition and some aspects of management as leadership (Pruzan, Mikkelsen, Miller, \& Miller, 2007). Research programs, such as the "Practical Wisdom Project" managed by the European Academy of Business in Society and the "Spiritual Capital Initiative" of the Yale Center for Faith and Culture, indicate the scientific interest in this topic. There are several contributions on the impact of both monotheistic religious tradition and Oriental philosophy and religion on managerial practical wisdom (Beekun, 2012; Cornuel, Habisch, \& Kletz, 2010; Daniels, 2014; de Bettignies, Keung Ip, Bai, Habisch, \& Lenssen, 2011; Dsouli, Khan, \& Kakabadse, 2012; El Garah, Beekun, Habisch, Lenssen, \& Loza Adaui, 2012; Melé \& Fontrodona, 2017; Naughton, Habisch, \& Lenssen, 2010; Weber- Berg, 2010; Yoneyama \& Yoneyama, 2007). Even if all these contributions take into account different traditions with different consequences for managerial approaches to problem-solving and decision-making, scholars agree on the strict connection between religious experience and managerial practices, according to a unitary view of human nature and the ineluctability of moral judgment in business problems (Krueger, 1986).

Among the different religious traditions, millenarian Christian reflection becomes relevant because of its importance in the development of Occidental thought and economics, as confirmed by Weber's and Novak's crucial contributions on the Christian roots of capitalism and the capitalistic spirit (Novak, 1993; Weber, 1934). The Catholic tradition feeds managerial practical wisdom from three different sources that share a common evangelic origin: Catholic Social Teaching, the action of religious orders and movements, which have generated economic experiences devoted to the common good and the practical experience of firms founded and managed by wise entrepreneurs.

In this context, the Rule of St. Benedict is a special deposit of spiritual capital, fruit of a millenarian Catholic monastic experience that is not separate from business administration. Even if the RSB was not born as a managerial code of conduct, monastic Benedictine experience had clear economic effects from its earliest days, and its content disciplines many economic aspects of monastic life. Therefore, the RSB can be seen in the overview of Christian experience that feeds spiritual capital and managerial practical wisdom.

\section{The Rule of St. Benedict as a spring of practical wisdom}

St. Benedict of Nursia lived in Italy at the turn of the fifth and sixth centuries, and is considered the real founder of coenobitical Occidental monasticism. St. Benedict's life history is recorded in the Second Book of Dialogs of St. Gregory the Great, a Benedictine monk who became the Roman Latin Pope in 590 AC. St. Gregory describes Benedict as a "man of God", whom life was remarkable more for his venerable virtues than for his reforming action on monasticism (Gregory I \& Gardner, 2010). It was only in the following centuries that historians and men of the Church recognized the crucial role played by Benedict and his monastic rule in developing the forms of religious life and of Occidental economic and social organization. The diffusion of Benedictine monasticism deeply impressed European ethical thinking during the Middle Ages, building the roots of modern society, even if St. Benedict himself had no particular political program, only the desire to discipline monastic life. 
The RSB is not a completely new literary work by St. Benedict of Nursia. He based his rule on coeval sources and, in particular, on the so-called Rule of the Master (de Vogüé, 1977; Pricoco, 1995). Nevertheless, if the RSB was not a revolution, during the following centuries it showed its importance as a clear summary of different contributions (Pricoco, 1995, p. XXVIII) and the peak of historical evolution, which overtook the former monastic Oriental experiences that were not suitable for the European cultural context (Rousseau, 2005). While St. Benedict was alive, his rule could be considered as one of the different monastic rules. However, the wide diffusion of the RSB throughout Europe showed its importance in religious and political life during the Carolingian age and especially after the reform sanctioned by the Abbotts' Council of Aachen in 817 AC, which adopted the RSB as the only monastic rule. In the following centuries, Benedictine monasteries were founded in all European regions and became increasingly powerful, as demonstrated by exemplary cases such as Farfa in Italy and Cluny in France (Constable, 2010; Hilpisch, 1989). Over the centuries, the Benedictine order separated into different religious families, such as the Cistercians, Trappists, and Camaldolese, but all these monasteries recognized the RSB as the central guide of monastic life.

The long and rich history of Benedictine monasticism is the first element that motivates us to consider the RSB as a deposit of spiritual capital and a spring of practical wisdom, valid also for management. St. Benedict wrote his rule in simple language because he had no philosophical ambition, and because he wanted to speak to all monks, even those without a cultured background (Penco, 1958, p. XL); so the absence of the word "phronesis" is not surprising. Nevertheless, the logical category of practical wisdom is implicit in his description of the character of abbots and other responsible members of monasteries (Tredget, 2010, p. 717), and he uses synonyms for phronesis when referring to the same semantic field. Reading the RSB, we find several terms, including sapientia, prudentia, discretio, providentia and the verb discernerre used to describe the wise posture that abbots and monks must maintain in their daily lives. In detail, sapientia and its derivatives occur 12 times, while these other words occur from three to five times in the text.

Consequently, the continuous reference to discernment and prudence testifies to the "phronetic" nature of the content of the RSB; however, there are also different characteristics of the historical evolution of the RSB that affirm its place as a spring of practical wisdom.

First, the RSB is not a philosophical text, but derives from St. Benedict's experience as a monk and an abbot in Montecassino; we can affirm that the RSB is the written summary of St. Benedict's practical wisdom, matured over his 30 years of monastic life. Its philological character (Pricoco, 1995, p. XXXIV) and the content itself (Lentini, 1952, p. XVII) show that the RSB cannot be the outcome of a legislative action; but rather, it is the fruit of the discernment of a person that has experimented with monastic life and the application of previous rules. This unique origin makes the RSB a "phronetic" text that aims to guide the practice of life. On the other hand, in the last chapter of the RSB, St. Benedict takes care to explain that the RSB is not a complete and detailed juridical code, but a basic rule that can help each monk to discern the right modus vivendi.

Second, the "phronetic" nature of the RSB emerges from its principal goal: directing the good life of individual monks and their communities. St. Benedict aims to address the abbots and the brethrento encourage them to assume wise decisions in their daily monastic life. In other words, the RSB hopes to shape good communities, in which all people practice spiritual and practical virtues, not least the dianoetic virtue of prudence, embodied in all their daily activities. If Aristotle logically unites phronēsis to the ultimate goal of eudaimonìa, St. Benedict guides his brethren to the apex of Christian life by building good communities where all situations - prayer, work, studies, and mutual service-are inspired by prudence.

Last, the plurimillenial history of the RSB confirms its "phronetic" character: monasticism has flourished on this pillar over the centuries, making European cultural, social, and economic development possible. Even though the RSB was not the only monastic rule available during the Middle Ages, Benedictine monastic experiences have survived in both other rules of stricter observance, such as the Rule of St. Colombanus, and reformed Benedictine monasteries, such as Cluny. The reason for this longevity is probably the more "phronetic" nature of the RSB that makes it possible to overcome all uncertainties by assuming decisions are inspired by essential prudence and indispensable discernment.

The RSB is not a charismatic text, but the "good fruit" of a way of life. Therefore, the RSB does not risk becoming a bureaucratic tool to manage rigid organizations, as is typical of charismatic power (Weber, 1921). The wide diffusion of Benedictine monasteries in Europe after the death of St. Benedict shows the importance of the RSB in building significant practices of religious life (Hilpisch, 1989); the RSB seems to fit Occidental society better than other monastic models, such as the Middle-Oriental eremitical experiences. During the Middle Ages, Benedictine communities saw their economic and social power increase and their influence on Church life become relevant, to the point of providing some popes, among whom was St. Gregorius Magnus, St. Benedict' biographer. 
The Benedictine monasteries have survived some difficult historical periods and continue to exist today, even if religion has changed in its expression. The Benedictine contribution to the life of the Church is another proof of the pervasive spiritual power of the RSB as a deposit of spiritual capital and a spring of practical wisdom.

\section{Research Design}

Certain scholars have explored some managerial implications of the RSB; in particular, there are some important studies on the model of leadership that emerges in the RSB (Bekker, 2009; Chan, McBey, \& Scott-Ladd, 2011) and the potential of the RSB as a tool in management education (Tredget, 2010). Kennedy (1999) examined the potential compatibility between the RSB and contemporary managerial theories, while other scholars have studied the RSB as a text useful for modern corporate (Kaufer, 1996; Rost, Inauen, Osterloh, \& Frey, 2010) and public governance (Inauen, Rost, Frey, Homberg, \& Osterloh, 2010).

Moreover, there are contributions by scholars and practitioners on the relevance of the RSB in human resource management (Dollard, Marett-Crosby, \& Garland, 2002; Galbraith \& Galbraith, 2004; Wolf \& Rosanna, 2007), and the connection between the RSB and organizational success (Folador, 2016; Skrabec, 2003). Other studies focus on the role of work in the RSB, as one of the more important elements of Benedictine monastic life that can affect contemporary work ethics (Malesic, 2015; Tredget, 2002).

Nevertheless, the RSB is a partially unexplored, but rich deposit of practical wisdom that can help in building good organizations and interpreting their ontology. The "phronetic" character of the RSB is at the root of this paper, according to the approach of Tredget (2010).

The research explores this important historical heritage by an in-depth analysis to answer to the following research question: how can RSB contribute to improve individual behavior into complex organizations by defining common good as organizational purpose?

This paper aims to contribute to managerial debate related to organizational purpose and on the impact of "good" organizations on individual virtues. In other words, our research overcome the individual level of RSB to explore organizational one.

In presenting our results, we adopt English translation from the Latin by Doyle (2001).

\section{Building the "good community"}

As mentioned before and as presented in previous studies, an individual level of practical wisdom clearly emerges into RSB. This dimension affects both style of leadership and individual behaviors. Nevertheless, by developing practical wisdom of monks, abbots, and other monasteries responsible, discipline of the RSB also enables coherent organization of the monastery, bringing out the communitarian level of the Rule and the crucial role assigned to organizational purpose. St. Benedict devotes a large proportion of his rule to regulating all offices of the monastery, in order to build a "good community" capable of helping all monks in their ascesis.

Love - of God and of one's brothers - is the basic rule for life in a monastery: the brethren are called to mutual service and the abbot is the community's servant, because the way to perfection in life passes through the construction of a community based on relational exchange and fraternity. The coenobitical form of monasticism is at the very center of the RSB and we cannot understand Benedictine monasticism without considering the communitarian choice instead of other forms of religious life, such as anchoritism or eremitism. The choice of the coenobitical model is not completely new, because communitarian monasticism originates from early monastic experiences and from the desert fathers' scripts (Gould, 1993). However, when St. Benedict illustrates diverse forms of monasticism and indicates his preference for coenobitism (RSB I), he not only traces the boundaries of his rule, but also selects the solution he considers the best for attaining eternal life.

In Benedictine thought, there is a strict connection between spiritual perfection and communitarian life, and all chapters of the RSB consistently aim to create the conditions to allow the monastery to become a good community. Reading the RSB, we can highlight four characteristics of this "good" community, which fosters the ascesis of monks as individuals and as members of the community itself.

First, stability characterizes the monastery (Feiss, 1999; Stewart, 1998) because only a durable relationship between individual monks and their community allows it to realize good actions: "Now the workshop in which we shall diligently execute all these tasks is the enclosure of the monastery and stability in the community" (RSB IV.78). St. Benedict wants his monks to remain in the same monastery so that they can patiently exercise all virtues and grow in their spiritual life. On the other hand, stability is one of the promises required of novices (RSB LVIII.17), because they must consciously choose monastic life and understand that communitarian life is their own way to reach spiritual perfection. 
Stability is so important in the RSB that even if hospitality is a duty, guests must make the choice of whether they want to become part of the community by accepting stability, or if they wish to maintain their temporary condition as guests (RSB LX.8, LXI.5). Therefore, stability is the conditio sine qua non for inclusiveness: monasteries are open communities, guests are welcome, and postulants can join the fraternity regardless their origins, but they have to accept stability as a fundamental provision to guarantee the good life of community.

Second, communitarian life includes different offices that have the same importance: prayer, study, and work (Bouyer, 2008), in continuity with the Biblical vision of the relationship between labor and life (e.g. Ecclesiastes 4:9). If liturgical offices and prayer are fundamental to developing the spiritual dimension of life and study of Bible is necessary to feed intellectual capabilities, likewise monks cannot renounce work because it is an unavoidable dimension of their life. The monks are directly responsible for the material organization of the monastery that is not delegated to servants, because all dimensions of monks' life are devoted to perfection and free time can distract souls from their way to eternal life. In other words, St. Benedict reconciles soul, mind and body in a "perfect" union of efforts to reach life goal: "Idleness is the enemy of the soul. Therefore the brethren should be occupied at certain times in manual labor, and again at fixed hours in sacred reading" (RSB XLVIII.1).

Manual labor does not degrade the social status of a monk, but elevates him to the level of the apostles and fathers; consequently, the brethren must accept their work joyfully, because in this way they contribute both to supporting the community and advancing their spiritual ascesis: "And if the circumstances of the place or their poverty should require that they themselves do the work of gathering the harvest, let them not be discontented; for then are they truly monks when they live by the labor of their hands, as did our Fathers and the Apostles" (RSB XLVIII.7-8).

The basis of a good community is labor, as an instrument to mutually serve all participants and to build a sustainable organization: if all brethren involve themselves in obtaining the monastery's economic independence, the sense of belonging grows and enforces community. On the other hand, the monastery becomes a workshop where monks walk the path to eternal life only if it achieves independence in economic terms and if monks can stay in the monastery without travelling around collecting alms. St. Benedict states that all necessary productive activity - e.g., the mill, water spring, and vegetable garden — should be internal to monastery, in order to seek economic sustainability (RSB LXVI.6-7).

Even if St. Benedict does not directly quote the Holy Bible, the relationship between material assets and labor discussed above mirrors the Biblical vocation to labor as reported into the book of Genesis, when God invites people to "cultivate and take care" (Genesis 2:15) of the garden of Eden. In the textual context of both the Holy Bible and the $\mathrm{RSB}$, people (monks) must work because they are the custodians of a gift and are responsible for the maintenance of this gift, which must be available to the community to whom they belong and to all humanity. Consequently, labor is not only an essential dimension of individual life, but also a fundamental aspect of communitarian life.

The particular relationship with material goods is the third characteristic of a good community: St. Benedict does not despise material substances, but bends them to the wellbeing of the community, excluding every individual interest or profit-making goal. There is a separation between brethren and material goods, but the RSB establishes a serene relation with the latter, because St. Benedict aims to create the best conditions for communitarian life and does not ask for intolerable sacrifices.

According to Biblical tradition, the RSB prescribes a balanced attitude toward materialism, excluding both greed and prodigality, because all things point toward God's will and eternal life. It is clear, for example, that cellarer must be wise in his administration of the monastery's businesses and avoid unscrupulous behavior: "He should be neither a miser nor a prodigal and squanderer of the monastery's substance, but should do all things with measure and in accordance with the Abbot's instructions" (RSB XXXI.12).

The brethren's vocation to labor has a clear communitarian connotation and does allow individual advantage or career opportunity, because each monk works to contribute mutually and fraternally to the community. St. Benedict makes this point clear, by prescribing punishment for monks that have exalted themselves: "But if any one of them becomes conceited over his skill in his craft, because he seems to be conferring a benefit on the monastery, let him be taken from his craft and no longer exercise it unless, after he has humbled himself, the Abbot again gives him permission" (RSB LVII.2-3).

The fourth characteristic of the good community built based on the RSB concerns how monks nominate their responsible officers. St. Benedict's idea of career and meritocracy is neat: no one obtains power over the community by an automatic mechanism or by other merits, except his wisdom and prudence in judgment. For example, when he describes the role of the Deans, St. Benedict makes clear that they are not the oldest monks, but the wisest ones among the monastery, because they have to be able to counsel the abbot in assuming his responsibility (RSB XXI). 
Any role that involves certain responsibility or visibility is given to monks who can usefully contribute to communitarian life, excluding any possible automatism. St. Benedict prescribes in the chapter devoted to weekly reader is paradigmatic: "The brethren are not to read or chant in order, but only those who edify their hearers" (RSB XXXVIII.12).

Finally, the Benedictine monastery is a good community as a result of both the content of the Rule and the primacy of the Rule itself over any other power. The RSB guides the community to the right path by cultivating practical wisdom within each participant in community, be it abbot, cellarer, or a simple monk.

\section{Managerial implications: is it only an individual choice?}

If scholars have already analyzed the potential of the RSB to shape wise leadership at the individual level, reading the RSB allows us to highlight further aspects inherent to the purpose of organizations. The first, and most important, contribution of the RSB to management and to business ethics concerns the vision of organizations as instruments for the common good. In St. Benedict's thought, a monastery is a complex organization based on the Rule, which is in turn not a combination of rigid restrictions, but rather, a way to build good relations with God, with the authorities, and with one's brethren. In other words, the practical wisdom derived from the RSB is not an individual affair, but something relevant to the basis of the institution itself. A good life enables good relations with others, and makes one capable of seeking the common good (Mancini, 2004, p. 99) as a fundamentally relational concept (Maritain, 1947). By making grow relational capabilities, RSB confirm the vision of firm as a community of persons (Melé, 2012) and the adoption of RSB in management practices can enforce social capital, and improve the solution of possible conflicts, as in the cases of agency problems (Rost et al., 2010).

A contribution to the ethical debate on managerial functions concerns the switch from the individual dimension of moral action in management to the communitarian dimension of business ethics. The RSB allows an understanding of how there is a "spirit" of community that involves individual choices, but that cannot be limited to them. Participation in an organized community makes individual choices able to reach goals otherwise unreachable, because of the relational and trustworthy nature of the community. It is not important which objectives (spiritual or economic) are at the basis of the organization: if a community of people share values and goals, it becomes stronger and abler to operate. Therefore, if each participant brings their individual needs and skills to an organization, there is an organizational metalevel in which individualities dissolve into the community. The goals of the community become primary, and individual goals can be reached only if communitarian aims are reached.

Obedience is the way that monks ratify their adherence to their community by sharing its values, objectives and internal rules: this is true not only for simple brethren, but for all those in responsible positions, and most of all, the abbots. Likewise, a firm can only work as a community if managers, entrepreneurs, and workers foster a sense of belonging. This sense of community is a deterrent against conflicts, because it bends individualities to fraternity and mutual service, making the common good the center of all organizational actions.

Clearly, a monastery is a hierarchical organization where monks must obey their leaders and RSB helps to develop ethical leadership, as previously highlighted by Chan and colleagues (2011). Nevertheless, monastic hierarchy is "wise" and is based on trust and practical wisdom, which no one must obey unless he shares the goals and values of the community and because he has discerned authority as an instrument to govern the community for the common good. Therefore, there is a nexus between leadership and the recognized purpose of the organization: the monk participates in monastery life and works hard because he has understood that coenobitical monasticism can help him to reach perfection in life. Similarly, in firms, the leadership becomes stronger if the organization aims for the common good and people share these values and goals.

The RSB has another important contribution that is potentially valuable in organizational life: the role assigned to labor and its relationship with the spiritual dimension of life. When St. Benedict prescribes manual work for monks, he recognizes the importance of combining diverse aspects of humankind - spirituality, the intellect, and materiality-in both personal and communitarian development. Likewise, if firms are communities of people, managers, entrepreneurs and workers must be free to cultivate themselves to maximize their contribution to common objectives. If in monasteries there is a need to emphasize manual labor to prevent idleness and conceit, businesses must also develop relational and spiritual capital to license themselves to operate.

Finally, the RSB makes clear that there is a relationship between organizational goals, practical wisdom, and sustainability that can be seen as a managerial reflection of "stability". Monks must be prudent to gain eternal life, and must persevere in their obedience to the RSB, while managers can orient their decision-making processes toward sustainability and overcome the narrow boundaries of individual, short-term interests, such as profit-seeking. 
Profitability is not excluded from the organizational purpose; monasteries - as for all firms - must be financial sustainable, but profit is only an instrument and not the principal aim of organization, as indeed, for Aristotle, it is not the aim of the virtuous person (Aristotle \& Rackham, 1982, Chapter I.5). Therefore, organizational purpose can help or, quite the opposite, hinder the development of managerial practical wisdom, depending on its durable or transitory nature. It is clear that the common good stimulates virtuous practice and prudent actions as the route to building good communities and sustainable businesses. Aristotelian thought attributes the character of stability to virtues (Aristotle \& Rackham, 1982, Chapter I.10), because only a wise posture can empower individual and communitarian practices and make them capable of reaching long-term goals. Therefore, the prescribed stability is not a chain that fastens individuals to the community, but the viaticum to reach a plentiful capacity to decide well and to build good relations within, and around, the organization.

\section{Conclusions}

This paper aimed to analyze the potential of the RSB as a tool to develop practical wisdom within businesses. Clearly, St. Benedict did not write his rule for managers or entrepreneurs, but the content of the RSB has universal validity and is a deposit of spiritual capital that aids contemporary people in their personal and communitarian discernment. His deep knowledge of humankind is the key to understanding his thoughts on monastery life and to applying his rule in building good communities licensed to operate in today's society. Cultivating spiritual capital is an opportunity to develop managerial practice and education, and the RSB is a precious souce of inspiration, available to all, not only those who belong to a religious community.

The RSB contributes a conceptual and ontological approach to organizations, but it can be operationalized and integrated in organizational practice in different ways; e.g., by using it as an instrument of business education (Tredget, 2010), by exercising spiritual coaching (Brescianini \& Pannitti, 2016) or by complementing the RSB within the ethical code of the firm, as in "Brunello Cucinelli SpA", where a Benedictine prior participate on the firm's ethics committee. The present article is written principally at the theoretical level, but further research on this theme could focus on a collection of managerial good practices that draws attention to the relationship between practical wisdom and organizational purpose.

\section{References}

Argandoña, A. (1998). The Stakeholder Theory and the Common Good. Journal of Business Ethics, 17(9), 1093-1102. https://doi.org/10.1023/A:1006075517423

Aristotle, \& Rackham, H. (1982). The Nicomachean ethics. Harvard University Press.

Baker, C., \& Skinner, H. (2005). Faith in Action - The dynamic connection between spiritual and religious capital. William Temple Foundation Research Project, (2002), 1-29

Beekun, R. I. (2012). Character centered leadership: Muhammad (p) as an ethical role model for CEOs. Journal of Management Development, 31(10), 1003-1020. https://doi.org/10.1108/02621711211281799

Bekker, C. J. (2009). Leading with the head bowed down: Lessons in leadership humility from the rule of St . Benedict of Nursia. Inner Resources for Leaders, 1(3), 1-10. Retrieved from http://www.christianity9to5.org/wpcontent/uploads/2013/04/bekker-on-humility.pdf

Benedict, \& Doyle, L. J. (2001). The rule of Saint Benedict. Liturgical Press. Retrieved from https://litpress.org/Products/2735/The-Rule-Of-Saint-Benedict

Berger, P., \& Hefner, R. (2003). Spiritual capital in comparative perspective. Spiritual Capital Planning Meeting. Retrieved from http://metanexus.org/archive/spiritualcapitalresearchprogram/pdf/Berger.pdf

Bouyer, L. (2008). Le sens de la vie monastique. Paris: Les Éd. du Cerf.

Brescianini, N., \& Pannitti, A. (2016). Spiritualità cristiana e Coaching. Roma: Edizioni La parola.

Brophy, M. (2015). Spirituality Incorporated: Including Convergent Spiritual Values in Business. Journal of Business Ethics, 132(4). https://doi.org/10.1007/s10551-014-2337-y

Burt, R. S. (1997). The Contingent Value of Social Capital. Administrative Science Quarterly, 42(2), 339. https://doi.org/10.2307/2393923

Burt, R. S. (2000). The Network Structure Of Social Capital. Research in Organizational Behavior, 22, $345-423$. https://doi.org/10.1016/S0191-3085(00)22009-1

Chan, C. C. A., McBey, K., \& Scott-Ladd, B. (2011). Ethical Leadership in Modern Employment Relationships: Lessons from St. Benedict. Journal of Business Ethics, 100(2), 221-228. https://doi.org/10.1007/s10551-0100676-X

Coleman, J. S. (1990). Foundations of social theory. Cambridge: Belknap Press of Harvard University Press.

Constable, G. (2010). The abbey of Cluny: a collection of essays to mark the eleven-hundredth anniversary of its 
foundation. Berlin: Lit.

Cornuel, E., Habisch, A., \& Kletz, P. (2010). The practical wisdom of the Catholic social teachings. Journal of Management Development, 29(7/8), 747-754. https://doi.org/10.1108/02621711011059185

Daniels, P. L. (2014). Practical wisdom for managing sustainable enterprises - synthesizing Buddhism and ecological economics. Journal of Management Development, 33(8/9), 797-811. https://doi.org/10.1108/JMD-09-20130121

de Bettignies, H., Keung Ip, P., Bai, X., Habisch, A., \& Lenssen, G. (2011). Practical wisdom for management from the Chinese classical traditions. Journal of Management Development, 30(7/8), 623-628. https://doi.org/10.1108/02621711111150155

de Vogüé, A. (1977). La règle de saint Benoît. Commentaire doctrinal et spirituel. Paris: Les Éditiones du Cerf.

Dollard, K., Marett-Crosby, A., \& Garland, H. (2002). Doing business with Benedict: the rule of St Benedict and business management : a conversation. New York: Continuum.

Dsouli, O., Khan, N., \& Kakabadse, N. K. (2012). Spiritual capital: The co- evolution of an ethical framework based on Abrahamic religious values in the Islamic tradition. Journal of Management Development, 31(10), 10581076. https://doi.org/10.1108/02621711211281843

El Garah, W., Beekun, R. I., Habisch, A., Lenssen, G., \& Loza Adaui, C. (2012). Practical wisdom for management from the Islamic tradition. Journal of Management Development, 31(10), 991-1000. https://doi.org/10.1108/02621711211281906

Feiss, H. (1999). Essential monastic wisdom: writings on the contemplative life. San Francisco: HarperSanFrancisco.

Folador, M. (2016). L'organizzazione perfetta. La regola di San Benedetto. Una saggezza antica al servizio dell'impresa moderna. Milano: Guerini Next.

Fontrodona, J., \& Sison, A. J. G. (2006). The Nature of the Firm, Agency Theory and Shareholder Theory: A Critique from Philosophical Anthropology. Journal of Business Ethics, 66(66), 33-42. https://doi.org/10.1007/s10551006-9052-2

Fowers, B. J. (2003). Reason and Human Finitude: In Praise of Practical Wisdom. American Behavioral Scientist, 47(4), 415-426. https://doi.org/10.1177/0002764203256947

Galbraith, C. S., \& Galbraith, O. I. (2004). The Benedictine Rule of Leadership: Classic Management Secrets You Can Use Today. Avon: Adams Media.

Gould, G. (1993). The desert fathers on monastic community. Oxford: Clarendon Press.

Gràcia, C. (2012). Spiritual Capital the New Border to Cross. Ramon Llull Journal of Applied Ethics, (3), 115-134. https://doi.org/http://dx.doi.org/10.4103/2013-8393.107303

Gregory I, P., \& Gardner, E. G. (2010). The dialogues of Saint Gregory the Great : re-edited with an introduction and notes. Merchantville: Evolution Pub.

Hilpisch, S. (1989). Histoire du monachisme bénédictin. Paris: Téqui.

Hittinger, R. (2008). The Coherence of the Four Basic Principles of Catholic Social Doctrine: An Interpretation. In M. S. Archer \& P. Donati (Eds.), Pursuing the Common Good: How Solidarity and Subsidiarity Can Work Together (pp. 75-123). Vatican City: Pontifical Academy of Social Sciences. Acta 14. Retrieved from www.pass.va/content/dam/scienzesociali/pdf/acta14/acta14-hittinger.pdf

Iannaccone, L. R., \& Klick, J. (2003). Spiritual Capital: An Introduction and Literature Review. In Spiritual Capital Planning Meeting, October 9-10, 2003, Cambridge, MA.

Inauen, E., Rost, K., Frey, B. S., Homberg, F., \& Osterloh, M. (2010). Monastic governance: Forgotten prospects for public institutions. American Review of Public Administration, 40(6), 631-653. https://doi.org/10.1177/0275074009360372

Intezari, A., \& Pauleen, D. J. (2014). Management Wisdom in Perspective: Are You Virtuous Enough to Succeed in Volatile Times? Journal of Business Ethics, 120(3), 393-404. https://doi.org/10.1007/s10551-013-1666-6

Kaufer, E. (1996). The Evolution of Governance Structures: Entrepreneurs and Corporations The Evolution of Governance Structures : Entrepreneurs and Corporations. Journal of Institutional and Theoretical Economics, 152(1), 7-29.

Keller, J. G., \& Helfenbein, R. (2008). Spirituality, Economics, and Education: A Dialogic Critique of \&quot;Spiritual Capital\&quot; Nebula, 5(4), 109-128.

Kennedy, M. H. (1999). Fayol's principles and the rule of St Benedict: Is there anything new under the sun? Journal of Management History, 5(5), 269-276. https://doi.org/10.1108/13552529910282259

Kennedy, R. G. (2006). The Good That Business Does (Vol. 9). Grand Rapids: Acton Institute. https://doi.org/10.1002/ejoc.200300023

Kinsella, E. A., \& Pitman, A. (2012). Phronesis as professional knowledge: Practical wisdom in the professions. Phronesis as Professional Knowledge: Practical Wisdom in the Professions, 1-177. 
https://doi.org/10.1007/978-94-6091-731-8

Koehn, D. (1995). A Role for Virtue Ethics in the Analysis of Business Practice. Business Ethics Quarterly, 5(3), 533. https://doi.org/10.2307/3857397

Koenig, H. G., \& Lewis, G. (2000). The healing connection: a world-renowned medical scientist discovers the powerful link between Christian faith and health. Nashville: Word Pub.

Krueger, D. A. (1986). The religious nature of practical reason: A way into the debate. Journal of Business Ethics, 5(6), 511-519. https://doi.org/10.1007/BF00380757

Lenssen, G., Roosevelt Malloch, T., Cornuel, E., \& Kakabadse, A. (2012). Practical wisdom in management from the religious and philosophical traditions. Journal of Management Development, 31(10). https://doi.org/10.1108/jmd.2012.02631jaa.001

Lentini, A. (1952). La Regola di S. Benedetto. Versione di Anselmo Lentini. Montecassino: Edizioni Cassinesi.

Malesic, J. (2015). "Nothing Is to Be Preferred to the Work of God": Cultivating Monastic Detachment for a Postindustrial Work Ethic. Journal of the Society of Christian Ethics, 35(1), 45-61.

Mancini, R. (2004). L'uomo e la comunità. Bose: Quiqaion.

Marcuse, H. (1964). One-Dimensional Man. London - New York: Routledge.

Maritain, J. (1947). La Personne et le bien commun. Paris: Desclée de Brouwer.

Melé, D. (2003). The Challenge of Humanistic Management. Journal of Business Ethics, 44, 77-88. https://doi.org/https://doi.org/10.1023/A:1023298710412

Melé, D. (2012). The Firm as a "Community of Persons": A Pillar of Humanistic Business Ethos. Journal of Business Ethics, 106(1), 89-101. https://doi.org/10.1007/s10551-011-1051-2

Melé, D., \& Fontrodona, J. (2017). Christian Ethics and Spirituality in Leading Business Organizations: Editorial Introduction. Journal of Business Ethics, 145(4), 671-679. https://doi.org/10.1007/s10551-016-3323-3

Melé, D., \& Schlag, M. (2015). Humanism in Economics and Business. Issues in Business Ethics (Vol. 43). Berlin: Springer. https://doi.org/10.1007/978-94-017-9704-7

Murphy, M. C. (2005). the Common Good. The Review of Metaphysics, 59(1), 133-164.

Naughton, M. J., Habisch, A., \& Lenssen, G. (2010). Practical wisdom in management from the Christian tradition. Journal of Management Development, 29(7/8). https://doi.org/10.1108/jmd.2010.02629gaa.002

Novak, M. (1993). The Catholic ethic and the spirit of capitalism. New York: Free Press.

Penco, G. (1958). Introduzione. In G. Penco (Ed.), Regula S. Benedicti (pp. I-CVIII). Firenze: La Nuova Italia.

Pricoco, S. (1995). Introduzione. In S. Pricoco (Ed.), La regola di San Benedetto e le Regole dei Padri (pp. VII-LXIV). Milano: Fondazione Lorenzo Valla.

Pruzan, P., Mikkelsen, K. P., Miller, D., \& Miller, W. (2007). Leading with wisdom : spiritual-based leadership in business. London: Greenleaf.

Puleen, D., \& Kupers, W. M. (2013). A Handbook of Practical Wisdom: Leadership , Organization and Integral Business (Book \& Resource Reviews). Academy of Management Learning \& Education, 12(2), 312-313. https://doi.org/10.5465/amle.2013.0113

Putnam, R. D. (2000). Bowling alone: the collapse and revival of American community. New York: Simon \& Schuster.

Roosevelt Malloch, T. (2010). Spiritual capital and practical wisdom. Journal of Management Development, 29(7/8), 755-759. https://doi.org/10.1108/02621711011059194

Rost, K., Inauen, E., Osterloh, M., \& Frey, B. S. (2010). The corporate governance of Benedictine abbeys. Journal of Management History, 16(1), 90-115. https://doi.org/10.1108/17511341011008331

Rousseau, P. (2005). Monasticism. In A. Cameron, B. Ward-Perkins, \& M. Whitby (Eds.), The Cambridge Ancient History (pp. 745-780). Cambridge: Cambridge University Press.

Scheler, M. (1913). Der Formalismus in der Ethik und die materiale Wertethik 1 (Vol. 1/2). Tübingen: Verlag von Max Niemeyer.

Schlag, M., \& Mercado, J. A. (2012). Free markets and the culture of common good. Berlin: Springer.

Schwartz, B. (2011). Practical wisdom and organizations. Research in Organizational Behavior, 31, 3-23. https://doi.org/10.1016/j.riob.2011.09.001

Sison, A. J. G., \& Fontrodona, J. (2012). The Common Good of the Firm in the Aristotelian-Thomistic Tradition. Business Ethics Quarterly, 22(02), 211-246. https://doi.org/10.5840/beq201222218

Sison, A. J. G., \& Fontrodona, J. (2013). Participating in the Common Good of the Firm. Journal of Business Ethics, 113(4), 611-623. https://doi.org/10.1007/s

Skrabec, Q. R. (2003). St. Benedict's Rule for business success. West Lafayette: Purdue University Press.

Smith, J. (2019). The Aristotelian Good Life and Virtue Theory. International Journal of Business and Social Science, 10(1). https://doi.org/10.30845/ijbss.v10n1p2

Spaemann, R. (1989). Glück und Wohlwollen. Versuch über Ethik. Stuttgart: Klett-Cotta. 
Spitzeck, H. (2011). An integrated model of humanistic management. Journal of Business Ethics, 99(1), 51-62. https://doi.org/10.1007/s10551-011-0748-6

Stewart, C. (1998). Prayer and community: the Benedictine tradition. Ossining: Orbis Books.

Tredget, D. A. (2002). "The Rule of Benedict" and its relevance to the world of work. Journal of Managerial Psychology, 17(3), 219-229. https://doi.org/10.1108/02683940210423123

Tredget, D. A. (2010). Practical wisdom and the Rule of Benedict. Journal of Management Development, 29(7/8), 716723. https://doi.org/10.1108/02621711011059158

Weber- Berg, C. (2010). Practical wisdom, an attempt for a Protestant re- formulation. Journal of Management Development, 29(7/8), 724-735. https://doi.org/10.1108/02621711011059167

Weber, M. (1921). Wirtschaft und Gesellschaft: Grundriss der verstehenden Soziologie. Lieferung 1. Tübingen: Mohr. Weber, M. (1934). Die protestantische Ethik und der Geist des Kapitalismus. Tübingen: Mohr.

Wolf, N., \& Rosanna, E. (2007). Die Kunst, Menschen zu führen. Reinbek: Rowohlt-Taschenbuch-Verl.

Wortham, R. A., \& Wortham, C. B. (2007). Spiritual Capital and a Good Life. Sociological Spectrum, 27(4), 439-452.

Yoneyama, E., \& Yoneyama, E. (2007). Phenomenology of life, Zen and management. Society and Business Review, 2(2), 204-217. https://doi.org/10.1108/17465680710757411

Zohar, D., \& Marshall, I. N. (2004). Spiritual Capital: Wealth We Can Live by. Oakland (CA): Berrett-Koehler Publishers. 